\title{
EVALUATION OF BLEACHABILITY ON PINE AND EUCALYPTUS KRAFT PULPS
}

\author{
Marcela Freitas Andrade ${ }^{1 *}$, Jorge Luiz Colodette ${ }^{1}$, Flávia Natalino Oliveira ${ }^{1}$
}

*Corresponding author: andrade-marcela@hotmail.com

\begin{abstract}
In recent decades, the pulp industry has been changing and improving its manufacturing processes in order to enhance production capacity, product quality and environmental performance. The aim of this study was to evaluate the bleachability effect on the efficient washing and alkaline leaching in eucalyptus and pine Kraft pulps using three different bleaching sequences: AD(EP)D, $\mathrm{A} / \mathrm{D}(\mathrm{EP}) \mathrm{DP}$ and $\mathrm{D}_{\mathrm{HT}}(\mathrm{EP}) \mathrm{DP}$. This study was carried out in two stages. In the first part, the optimum conditions for pulp bleaching in order to achieve a brightness of $90 \%$ ISO were established. The second step was a comparative study between the pulps that received alkaline leaching and efficient washing with reference pulp (without treatment). The brightness, viscosity, kappa number and HexA in pulp were analyzed. The three sequences studied reached the desired brightness, but the sequence AD(EP)D produced a lower reagent consumption for the same brightness. In the three sequences studied, the efficient washing of the pulp after oxygen delignification has contributed significantly to the removal of dissolved organic and inorganic materials in the pulp and the alkaline leaching decreased significantly the pulp kappa number due to a higher pulp delignification and bleachability.
\end{abstract}

Key words: Delignification, alkaline leaching, efficient washing.

\section{AVALIAÇÃo DA BRANQUEABILIDADE DE POLPAS KRAFT DE PINUS E EUCALIPTO}

RESUMO: Nas últimas décadas, a indústria de celulose vem modificando e aperfeiçoando os seus processos fabris, com o objetivo de melhorar a sua capacidade de produção, a qualidade de seus produtos e o seu desempenho ambiental. Objetivou-se, neste trabalho, avaliar o efeito da lavagem eficiente e da lixiviação alcalina de polpas Kraft de eucalipto e pinus nas suas branqueabilidades, utilizando-se três diferentes sequências de branqueamento: $A D(E P) D, A / D(E P) D P$ e $D_{H T}(E P) D P$. O presente trabalho foi realizado em duas etapas. Na primeira parte, foram estabelecidas as condições ótimas de branqueamento da polpa, a fim de se atingir uma alvura de $90 \%$ ISO. Na segunda etapa, foi realizado um estudo comparativo entre as polpas que receberam a lixiviação alcalina e a lavagem eficiente com uma polpa de referência que não recebeu esse tratamento. Para a discussão dos resultados, foram realizadas análises de alvura, viscosidade, ácidos hexenurônicos e número kappa na polpa de celulose. As três sequências estudadas atingiram a alvura desejada, mas a sequência $A D(E P) D$ obteve um menor consumo de reagentes para uma mesma alvura. Nas três sequências estudadas, a lavagem eficiente da polpa após a deslignificação com oxigênio contribuiu significativamente com a remoção de materiais orgânico e inorgânico dissolvidos na polpa, e a lixiviação alcalina da polpa reduziu o número kappa significativamente proporcionando uma maior deslignificação e melhor branqueabilidade das polpas de celulósicas.

Palavras-chave: Deslignificação, lixiviação alcalina, lavagem eficiente.

\section{INTRODUCTION}

In recent decades, the pulp industry has been changing and improving its manufacturing processes in order to enhance production capacity, product quality and environmental performance. The presence of dissolved organic and inorganic material in the pulp after washing hampers the efficient operation of the bleaching process, mainly due to a higher consumption of chemicals and the consequent increase of color and chemical (COD) and biological (BOD) oxygen demand from industrial plant effluent. The alkaline leaching pulp has as a purpose to remove lignin trapped on the cellulose fibers, resulting in a lower kappa number and lower reagent consumption in the next stage. In alkaline delignification, lignin and carbohydrate are dissolved and it gives as result a decrease in pulp yield.

${ }^{1}$ Universidade Federal de Viçosa - Viçosa, Minas Gerais, Brazil
The pulp washing in bleaching removes dissolved organic and inorganic materials that provide suitable conditions for the subsequent bleaching stage minimizing disturbances and reducing the consumption of reagents (FRASSÃO, 2008). The best possible washing result is obtained when clean water is applied for all washing steps, typically, the pulp washing is done in a countercurrent system, where clean water is applied at the end of the wash cycle and the final filtrate is reused in the previous steps, moving in countercurrent to the input side of the cellulose in the system.

Studies of alkaline leaching of the pulp after the oxygen delignification stage, showed that an increase in the alkali charge and temperature provides greater reductions in kappa number and viscosity (DENCE; REEVE, 1996).

According to authors Li and MacLeod (2009), large amounts of residual lignin can be removed from the

Cerne, Lavras, v. 19, n. 3, p. 433-439, jul./set. 2013 
Kraft pulp by the alkaline leaching of appropriate process conditions. According to these authors, the amount of removed lignin increased with high concentrations of $\mathrm{NaOH}$ and high temperatures. The oxygen-free alkaline leaching did not affect cellulose at temperatures up to $100^{\circ} \mathrm{C}$, but there was an increase in the extraction of hemicelluloses as we increased the concentration of $\mathrm{NaOH}$.

At high $\mathrm{pH}$, the lignin reacts with the alkali, especially at high temperatures. The fibers are swollen in alkaline conditions, a favorable lignin transfer occurring out of the fibers (VILPPONEN, 1987).

The aim of this study was to evaluate the bleachability effect on efficient washing and alkaline leaching in eucalyptus and pine Kraft pulps using three different bleaching sequences: $\mathrm{AD}(\mathrm{EP}) \mathrm{D}, \mathrm{A} / \mathrm{D}(\mathrm{EP}) \mathrm{DP}$ and $\mathrm{D}_{\mathrm{HT}}(\mathrm{EP}) \mathrm{DP}$.

\section{MATERIALS AND METHODS}

Thirteen different cellulosic pulps from oxygen delignification stage were used: eleven eucalyptus pulps (1 to 11) and two pine pulps (12 and 13). The initial characterization of the pulps is shown in Table 1.

Table 1 - Initial characterization of cellulosic pulps.

Tabela 1 - Caracterização inicial das polpas celulósicas.

\begin{tabular}{cccccc}
\hline Pulps & $\begin{array}{c}\text { Brightness } \\
(\% \text { ISO) }\end{array}$ & $\begin{array}{c}\text { Kappa } \\
\mathrm{N}^{\mathrm{o}}\end{array}$ & $\begin{array}{c}\text { Viscosity } \\
\left(\mathrm{dm}^{3} / \mathrm{kg}\right)\end{array}$ & $\begin{array}{c}\text { Hexa's } \\
(\mathrm{mmol} / \mathrm{Kg})\end{array}$ & $\begin{array}{c}\text { COD } \\
\left(\mathrm{Kg} \mathrm{O}_{2} / \mathrm{odt}\right)\end{array}$ \\
\hline 1 & 62.7 & 9.5 & 1037 & 49.7 & 5.5 \\
2 & 60.9 & 10.4 & 1095 & 57.3 & 8.1 \\
3 & 54.7 & 10.5 & 1077 & 58.3 & 92 \\
4 & 51.5 & 9.3 & 1004 & 44.4 & 6.5 \\
5 & 44.7 & 9.3 & 944 & 45.0 & 10.9 \\
6 & 51.3 & 7.9 & 741 & 22.5 & 1.7 \\
7 & 58.1 & 9.8 & 1034 & 52.9 & 8.0 \\
8 & 59.7 & 9.9 & 961 & 53.3 & 5.4 \\
9 & 61.8 & 10.5 & 1116 & 55.7 & 25.5 \\
10 & 59.9 & 10.8 & 1215 & 49.0 & 25.5 \\
11 & 62.1 & 9.9 & 997 & 46.7 & 23.6 \\
12 & 43.0 & 9.8 & 956 & 22.9 & 23.8 \\
13 & 32.9 & 10.4 & 701 & 13.2 & 4.8 \\
\hline
\end{tabular}

COD - (Chemical Oxygen Demand)

This study was carried out in two stages. In the first part, the optimum conditions for pulp bleaching in order to achieve a brightness of $90 \%$ ISO were established. The second step was a comparative study between the pulps that received alkaline leaching and efficient washing with reference pulp (without treatment).

The pulps from oxygen delignification stage were washed efficiently with $50 \mathrm{~m}^{3}$ of distilled water per ton of dry pulp. After efficient washing was performed leaching alkaline (treatment with $\mathrm{NaOH}$ ). This stage was carried in polyethylene bags with samples of known weights of pulps, the following conditions: $90 \mathrm{~min}, 90^{\circ} \mathrm{C}, 10 \%$ consistency and $20 \mathrm{~kg} / \mathrm{odt}$ of $\mathrm{NaOH}$. After hand mixing of the pulp, water and $\mathrm{NaOH}$, the material was heated in a microwave oven until the temperature of treatment and transferred to a steam bath equipped with a thermostat, which was maintained at a specified time and constant temperature.

Three bleaching sequences were utilized: $\mathrm{AD}(\mathrm{EP})$ D (sequence 1), A/D(EP)DP (sequence 2) and DHT(EP) DP (sequence 3). The conditions of the initial stage of bleaching can be observed in Table 2 .

Table 2 - Operating conditions of the initial stages of bleaching.

Tabela 2 - Condições operacionais dos estágios iniciais de branqueamento.

\begin{tabular}{lccc}
\hline Conditions & $\mathrm{A}$ & $\mathrm{D}$ & $\mathrm{D}_{\mathrm{HT}}$ \\
\hline Time, min & 120 & 15 & 120 \\
Temperature, ${ }^{\circ} \mathrm{C}$ & 95 & 85 & 95 \\
Consistency, $\%$ & 10 & 10 & 10 \\
$\mathrm{H}_{2} \mathrm{SO}_{4}, \mathrm{~kg} / \mathrm{odt}$. & $*$ & - & $*$ \\
$\mathrm{NaOH}, \mathrm{kg} /$ odt. & 20.0 & $*$ & - \\
Kappa Factor & - & 0.20 & 0.20 \\
\hline
\end{tabular}

* Variable dosage for $\mathrm{pH}$ adjustment.

A - Acid Treatment

D - Delignification with chlorine dioxide

$\mathrm{D}_{\mathrm{HT}}$ - Delignification with chlorine dioxide of high temperature

For sequences 1 and 3, the pulp was washed with $9 \mathrm{~m}^{3}$ of distilled water after the reaction, to simulate industrial washing. The pulp of the sequence 2 was not washed after the acid stage and then chlorine dioxide (A/D) was added immediately, after this stage, the pulp was washed with $9 \mathrm{~m}^{3}$ of distilled water.

The conditions used for extraction with peroxide (EP) (sequences 1, 2 and 3), chlorine dioxide bleaching end (sequences 1,2 and 3) and bleaching with hydrogen peroxide end (after 2 and 3 ) are presented in Table 3.

Cerne, Lavras, v. 19, n. 3, p. 433-439, jul./set. 2013 
Table 3 -Conditions used in the sequences 1, 2 and 3.

Tabela 3 - Condições utilizadas nas sequências 1, 2 e 3.

\begin{tabular}{lccc}
\hline Conditions & $(\mathrm{EP})$ & $\mathrm{D}$ & $\mathrm{P}$ \\
\hline Time, min & 90 & 120 & 60 \\
Temperature, ${ }^{\circ} \mathrm{C}$ & 85 & 80 & 90 \\
Consistency, $\%$ & 10 & 10 & 10 \\
$\mathrm{H}_{2} \mathrm{SO}_{4}, \mathrm{~kg} /$ odt. & - & 1.0 & - \\
$\mathrm{NaOH}, \mathrm{kg} / \mathrm{odt}$ & 10.0 & - & 6.0 \\
$\mathrm{H}_{2} \mathrm{O}_{2}, \mathrm{~kg} / \mathrm{odt}$. & 3.0 & - & 2.0 \\
$\mathrm{ClO}_{2}, \mathrm{~kg} / \mathrm{odt}$ & - & $*$ & - \\
$\mathrm{MgSO}_{4}, \mathrm{~kg} / \mathrm{odt}$ & - & - & 3.0 \\
\hline
\end{tabular}

*Variable dosage to achieve the desired brightness.

(EP) - Extraction with hydrogen peroxide

D - Bleaching with chlorine dioxide

P - Bleaching with hydrogen peroxide

At the end of the reaction time of each stage, the pulp was washed with distilled water, a ratio of $9 \mathrm{~m}^{3}$ of distilled water per ton of dry pulp.

The performance of each stage was evaluated based on the kappa number, viscosity, HexA's and pulp brightness.

The analysis of kappa number, pulp brightness and viscosity were measured by the TAPPI method (TAPPI STANDARD PROCEDURES, 1999). The HexA's in the pulp were measured by the procedure established by Vuorinen et al. (1996). The analyses of COD of the effluents were measured according to the procedure Standard Methods for the Examination of water and Wastewater (AMERICAN PUBLIC HEALTH ASSOCIATION - APHA, 1998).

\subsection{Statistical analysis}

The bleaching Statistical analysis were performed using Statistic 7.0 software. It was done a variance analysis (ANOVA) using a significance level of 5\%.

The tested hypotheses were the following:

- H0: all averages are equal, there is no significant difference between sequences, and

- Ha: there is an average statistically different from the others, at least.

If the ANOVA showed significant differences among the sequences, it was applied the Tukey test. For averages statistically equals, same letters were used; and for averages statistically different, also were used different letters.

\section{RESULTS AND DISCUSSION}

\subsection{Pre bleaching}

\subsubsection{Effect of pulp washing efficiency}

The pulps from the pre $\mathrm{O}_{2}$ were washed with $50 \mathrm{~m}^{3}$ of water per ton of dry pulp to remove as much organic and inorganic materials dissolved in the pulp after the pre$\mathrm{O}_{2}$. In Figure 1 it was observed the effect of the degree of washing when compared with the reference pulps (washed with $9 \mathrm{~m}^{3}$ of water per ton of dry pulp - pulp pre $\mathrm{O}_{2}$ ).
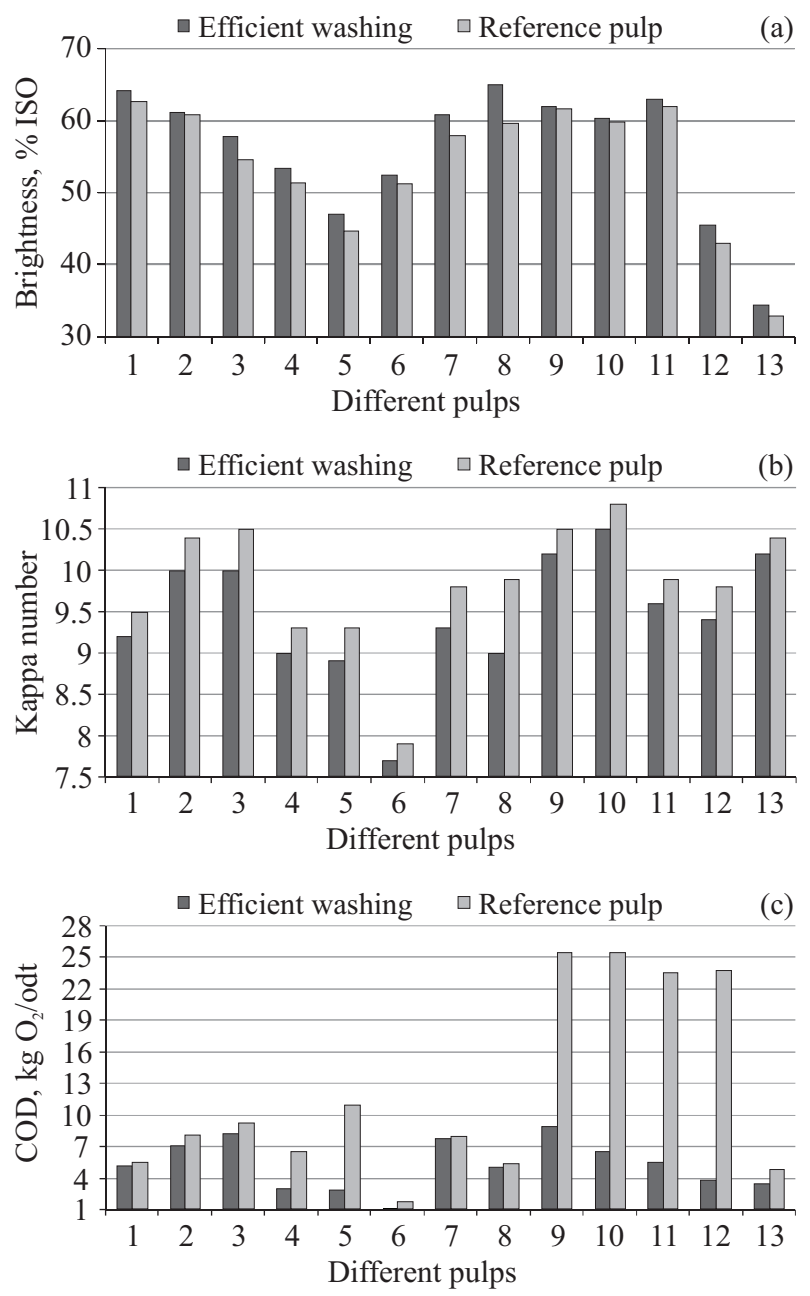

Figure 1 - Effect of efficient washing of cellulose pulp: (a) The effect on brightness; (b) The effect on the kappa number; (c) The effect on COD.

Figura 1 - Efeito da lavagem eficientes das polpas de celulose: (a) Efeito na alvura; (b) Efeito no número kappa; (c) Efeito na $D Q O$.

Cerne, Lavras, v. 19, n. 3, p. 433-439, jul./set. 2013 
The efficient washing of the pulp provided a small gain in brightness in the pulp and consequently a decrease in kappa number, this occurred due to a higher removal of organic material present in the pulps (Figure $1 \mathrm{c}$ ). By increasing the amount of organic compounds contained in the liquor, it causes higher oxygen consumption and higher COD.

According to Piotto (2003), an efficient washing of brown pulp reduces the consumption of oxidant in the bleaching. The efficient washing before the first bleaching stage will reduce the load of organic compounds. This results in decreased concentrations of AOX, BOD, and COD in the effluent.

The dissolved material that goes with the pulp to the stage of delignification and/or bleaching can damage the delignification or bleaching, and also increase the consumption of bleaching chemical, as lower final brightness of pulp or low resistance of this (TRINDADE, 2003).

\subsubsection{Effect of alkaline leaching}

After efficient washing, the pulps passed through an alkaline treatment. Figure 2 shows the effect of alkaline leaching compared with the reference pulps.

Pulps which received treatment with alkali showed a higher brightness and lower kappa number compared to the reference Pulps. This is explained by the fact that the alkali remove certain amount of lignin. In a study conducted by Li and MacLeod (1993) it was observed that the alkaline leaching of kraft cellulosic pulp provided a higher reduction of the kappa number in the leached when compared to the reference pulp. The amount of lignin removed was $25-31 \%$ higher in the pulp treated with $\mathrm{NaOH}$.

The content of HexA was also diminished with the alkaline leaching, being the kappa number consequently reduced. Because part of the kappa number is composed of HexA's.

In strong alkaline solution and high temperatures, the HexA's decompose slowly (VENTORIM, 2004).

\subsection{Bleaching}

The pulp that received efficient washing and treated with alkali were then bleached, using three different sequences: $\mathrm{AD}(\mathrm{EP}) \mathrm{D}$ (sequence 1), $\mathrm{A} / \mathrm{D}(\mathrm{EP})$ $\mathrm{DP}$ (sequence 2) and $\mathrm{D}_{\mathrm{HT}}(\mathrm{EP}) \mathrm{DP}$ (sequence 3). Figure 3 shows the profiles of brightness, kappa number and content of HexA's during the first bleaching stage by the three studied sequences.

Cerne, Lavras, v. 19, n. 3, p. 433-439, jul./set. 2013
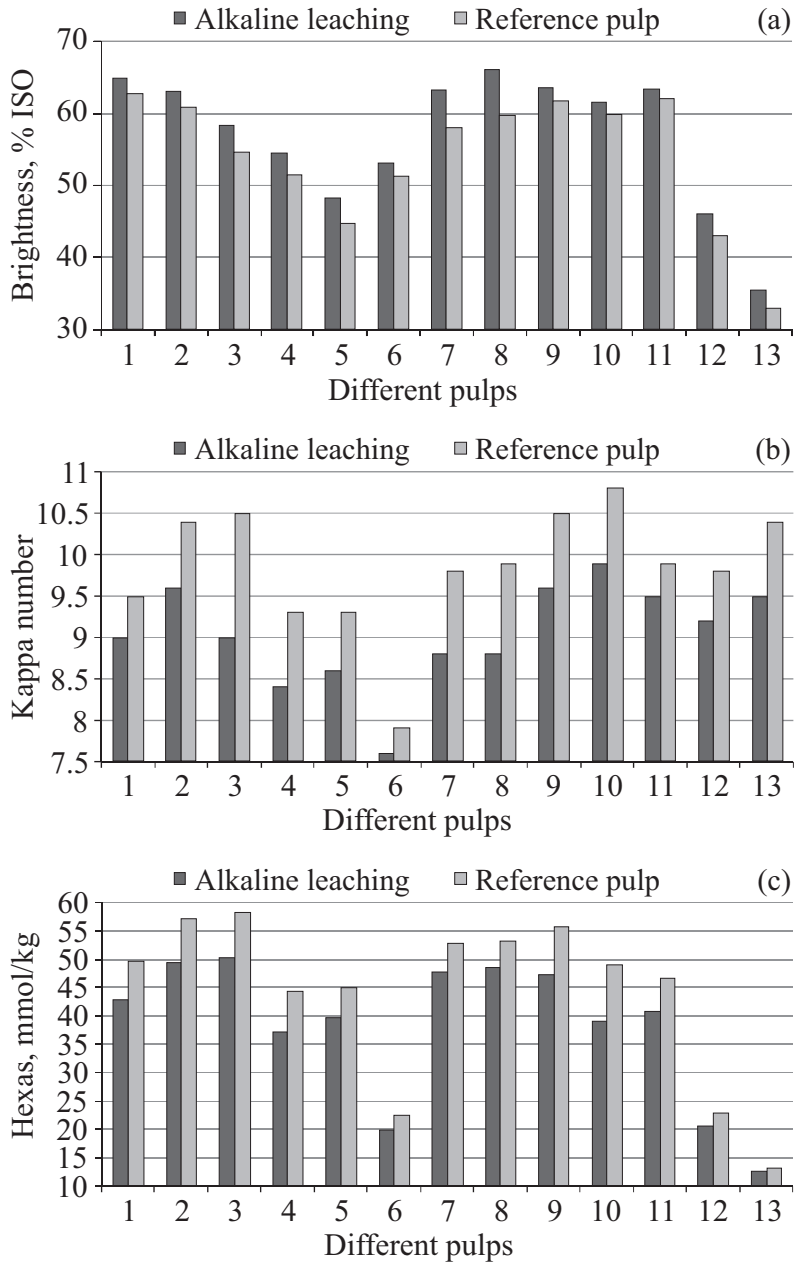

Figure 2 - Effect of alkaline leaching of pulps: (a) The effect on brightness; (b) The effect on kappa number; (c) The effect on HexA's content.

Figura 2 - Efeito da lixiviação alcalina das polpas de celulose: (a) Efeito na alvura; (b) Efeito no número kappa; (c) Efeito no teor HexA's.

As show in Figure 3 that the brightness values of the pulps conducted by sequence $\mathrm{D}_{\mathrm{HT}}$ were higher than the other brightness values of other bleaching sequences, and hence the pulps conducted by the following $\mathrm{D}_{\mathrm{HT}}$ had a lower kappa number. This can be explained by the chlorine dioxide at high temperatures degrade lignin in pulps.

In relation the HexA's content in pulps it is observed that the initial stage of bleaching $\mathrm{D}_{\text {нт }}$ promoted a greater reduction of HexA's, followed by the stages $\mathrm{A} / \mathrm{D}$ and A, respectively. The chlorine dioxide stage has a higher reaction rate with the HexA's than the stage of acid 

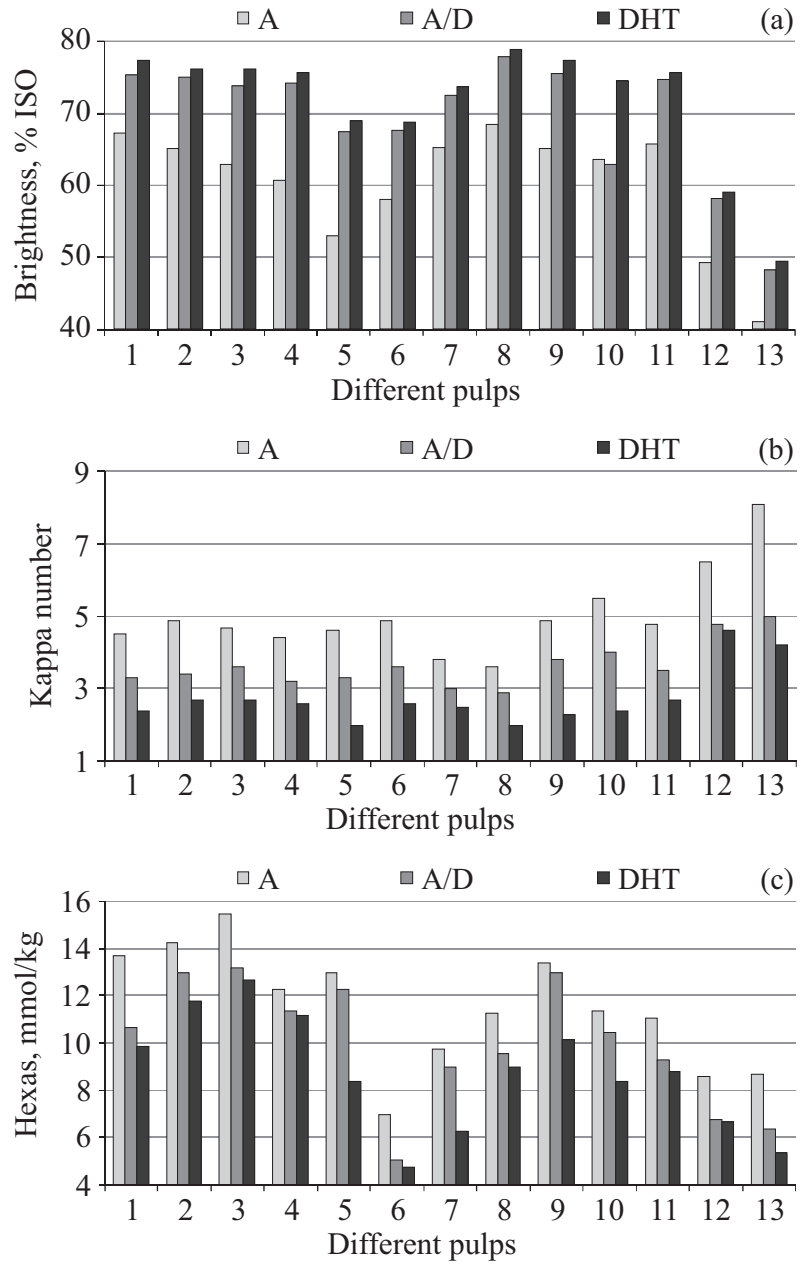

Figure 3 - Initial stage of bleaching by the three studied sequences. (a) Profile the brightness; (b) Profile kappa number, (c) Profile HexA content's.

Figura 3 - Estágio inicial de branqueamento pelas três sequências estudadas. (a) Perfil de alvura; (b) Perfil de número kappa; (c) Perfil de teor de HexA's.

hydrolysis (VENTORIM, 2004), although the chlorine dioxide does not react with HexA's. However, the reagents are in equilibrium with chlorine dioxide $\left(\mathrm{Cl}_{2}\right.$ and $\left.\mathrm{HClO}\right)$ in the reaction system are responsible for the reaction.

The amount of HexA's in pine pulps (pulp 12 and 13) is smaller than in the eucalyptus pulps (pulps 1 to 11). The hardwood pulps contain more hexenuronic acids groups than softwood, both produced by the kraft pulping (JIANG et al., 2000), since hardwood contain more 4-O-methylglucuronoxylan than softwood, which is the precursor of hexenuronic acids.
According to Shimizu (1981 cited by JIANG et al., 2000) the rate of hexenuronic acid hydrolysis increases nine times with the increase of reaction temperature from 80 to $100^{\circ} \mathrm{C}$. However, hydrolysis in acidic medium, even when intensified $\left(1 \mathrm{~h} / 110^{\circ} \mathrm{C} / \mathrm{pH} 3.5\right)$, does not result in complete degradation of hexenuronic acids in kraft pulps.

\subsection{Total active chlorine dosage at the end of bleaching}

All three studied sequences reached a desired brightness of 90.0 more or less $0.5 \%$ ISO. Figure 4 shows the consumption of total active chlorine (CAT, $\mathrm{Kg} / \mathrm{odt}$ ) of each sequence over bleaching.

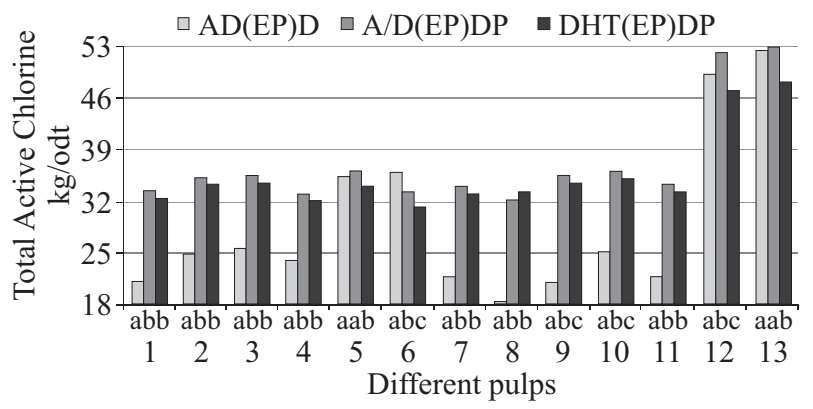

Note: The averages, shown the same letters in each cellulosic pulp, are not significantly difference as determined by Tukey's test at a $5 \%$ significance.

Nota: As médias, apresentadas com as mesmas letras em cada polpa celulósica, não diferem entre si pelo teste de Tukey, a 5\% de probabilidade.

Figure 4-CAT* used in the bleaching of pulps by three different sequences.

*CAT: $\mathrm{ClO}_{2}$ (as chlorine) $+2.09 * \mathrm{H}_{2} \mathrm{O}_{2}$

Figura $4-C A T^{*}$ usado nas três diferentes sequências de branqueamento.

*CAT: $\mathrm{ClO}_{2}$ (como cloro) $+2.09 * \mathrm{H}_{2} \mathrm{O}_{2}$

The sequence showed that a lower dosage of CAT was the sequence $\mathrm{AD}(\mathrm{EP}) \mathrm{D}$, followed by sequences $\mathrm{D}_{\mathrm{HT}}(\mathrm{EP}) \mathrm{DP}$ and $\mathrm{A} / \mathrm{D}(\mathrm{EP}) \mathrm{DP}$, respectively. This result was probably due to the absence of the final stage $\mathrm{P}$ in the sequence 1; and shows the positive effect of an intermediate washing, with a lower dosage of CAT without affecting the final brightness of eucalyptus pulps. Studies conducted by Milanez et al. (2008) showed optimal conditions of bleaching to kraft eucalyptus pulp, using short sequences. As for the pine pulps (pulps 12 and 13), is shown that sequence 1 did not obtain the lower charge of CAT. Evidencing that for pine pulps, short sequences of bleaching are not the most recommended.

Cerne, Lavras, v. 19, n. 3, p. 433-439, jul./set. 2013 


\subsection{Effect of final viscosity in the three studied sequences}

The final viscosity of each bleaching sequence studied is shown in Figure 5.

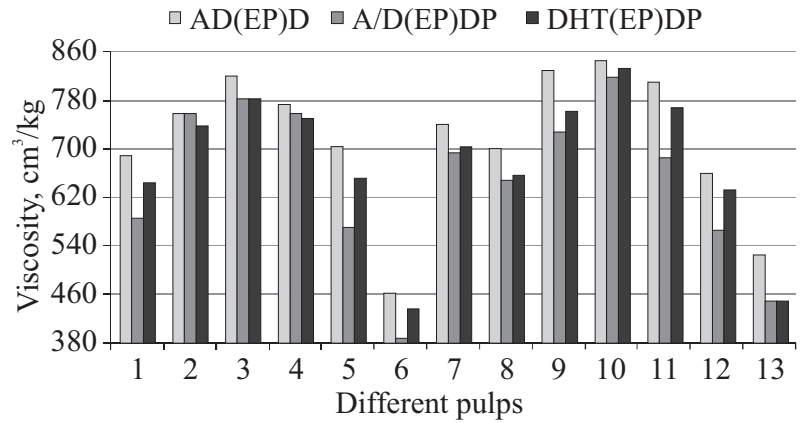

Note: The averages, shown the same letters in each cellulosic pulp, are not significantly difference as determined by Tukey's test at a $5 \%$ significance.

Nota: As médias, apresentadas com as mesmas letras em cada polpa celulósica, não diferem entre si pelo teste de Tukey, a 5\% de probabilidade.

Figure 5 - Evaluation of the final viscosity of the studied pulps by the three bleaching sequences.

Figura 5-Avaliação da viscosidade final das diferentes polpas estudadas pelas três sequências de branqueamento.

The viscosity values from eucalyptus pulps (pulps 1 to 11) were higher than those pine pulps (pulps 12 and 13), due initial viscosity of the pine pulp show low values and due the higher loss of viscosity the pine pulps during the bleaching in comparison to the eucalyptus pulps. The higher losses in the case of pine are explained by a higher demand for chlorine dioxide to achieve the brightness of $90 \%$ ISO.

The final viscosity from the pulps conducted by the $\mathrm{AD}(\mathrm{EP}) \mathrm{D}$ sequence were higher than the other sequences. This fact can be explained due low reagents demand in sequence 1 and a low carbohydrate degradation in this sequence.

Similar results are found in literature. According Eiras (2002), AD technology is more efficient because it results in economy of chlorine dioxide three times higher than $\mathrm{A} / \mathrm{D}$ and $\mathrm{D}_{\mathrm{HT}}$ technologies, and besides it is produces pulps with higher viscosity.

\section{CONCLUSIONS}

The efficiently washed pulps had a lower COD (kg/odt) than the reference pulps; efficient washing has resulted in pulps that are cleaner and easier to bleach.
The alkali treatment reduced the kappa number of the pulp and led to a small reduction in the HexA's content of pulp compared to the reference pulps.

The pulps conducted by the initial stage of $\mathrm{D}_{\text {Hт }}$ bleaching resulted in pulps with higher brightness levels and lower levels of HexA's.

The AD(EP)D sequence presened a lower reagent consumption for the same brightness and a final viscosity higher than the other studied sequences.

\section{REFERENCES}

AMERICAN PUBLIC HEALTH ASSOCIATION. Standard methods for the examination of water and wastewater. $20^{\text {th }}$ ed. Washington: AWWA-WPCF, 1998.

DENCE, E.; REEVE, W. D. Pulp bleaching. Atlanta: Tappi, 1996. $232 \mathrm{p}$.

EIRAS, K. M. M. Otimização do estágio de branqueamento de polpa kraft de eucalipto com dióxido de cloro em alta temperatura. 2002. 88 p. Dissertação (Mestrado em Ciência Florestal) - Universidade Federal de Viçosa, Viçosa, 2002.

FRASSÃO, T. V. Medição de eficiência dos lavadores de branqueamento. 2008. 51 p. Dissertação (Mestrado em Tecnologia de Celulose e Papel) - Universidade Federal de Viçosa, Viçosa, 2008.

JIANG, Z. H.; LIEROP, B. V.; BERRY, R. Hexenuronic acid groups in pulping and bleaching chemistry. Tappi Journal, Atlanta, v. 83, n. 1, p. 167-175, 2000.

\section{LI, J.; MACLEOD, J. M. Alkaline leaching of kraft pulps} for lignin removal. Disponível em: <http://www.tappi.org/s_ tappi/sec.asp?CID=84\&DID=104>. Acesso em: 5 fev. 2009.

LI, J.; MACLEOD, J. M. The effects of alkaline leaching on pulps bleachability and physical properties. Tappi Journal, Atlanta, v. 76, n. 12, p. 159-166, Dec. 1993.

MILANEZ, A. F.; COLODETTE, J. L.; CARVAlHO, A. M. M. L. Condições ótimas para branquear polpa kraft de eucalipto com uma sequência de três estágios. Scientia Forestalis, Piracicaba, v. 36, n. 78, p. 105-113, jun. 2008.

PIOTTO, Z. C. Eco-eficiência na indústria de celulose e papel. 2003. 357 p. Tese (Doutorado em Engenharia) Universidade de São Paulo, São Paulo, 2003.

TAPPI STANDARD PROCEDURES. Tappi. Atlanta, 1999.

Cerne, Lavras, v. 19, n. 3, p. 433-439, jul./set. 2013 
TRINDADE, H. de S. A importância da lavagem da polpa nos estágios de branqueamento. 2003. 62 p. Dissertação (Mestrado em Tecnologia de Celulose e Papel) - Universidade Federal de Viçosa, Viçosa, 2003.

VENTORIM, G. Estudo das reações da lignina e dos ácidos hexenurônicos em polpa Kraft de eucalipto com oxigênio, dióxido de cloro, ácido sulfúrico e ozônio. 2004. 187 p. Tese (Doutorado) - Universidade Federal de Viçosa, Viçosa, 2004.
VILPPONEN, A. Deslignification of kraft pulp by deep wash. 1987. 70 p. Thesis (Ph.D. in Finnish) - Helsinki University of Technology, Espoo, 1987.

VUORINEN, T.; TELEMAN, A.; FAGERSTROM, P.; BUCHERT, J.; TENKANEN, M. Selective hydrolysis of hexenuronic acid groups and its application in ECF and TCF bleaching of kraft pulps. In: INTERNATIONAL PULP BLEACHING CONFERENCE, 1., 1996, Atlanta. Proceedings... Atlanta: Tappi, 1996. p. 43-51.

Received: April 19, 2011; accepted: January 25, 2013.

Cerne, Lavras, v. 19, n. 3, p. 433-439, jul./set. 2013 
